\title{
Beckett, Censorship and the Problem of Parody
}

\author{
Seán Kennedy \\ Saint Mary's University, Halifax, Canada
}

Copyright (c) 2019 by Seán Kennedy. This text may be archived and redistributed both in electronic form and in hard copy, provided that the author and journal are properly cited and no fee is charged for access.

\begin{abstract}
In a forceful critique of previous scholarship, Lloyd (Meadhbh) Houston discerns evidence of "sectarian eugenicism" in Beckett's writings. It is a startling claim, and there are problems to it. In particular, I suggest, Houston ignores the issue of tone: Beckett's use of parody. Responding to Houston's critique, I offer some thoughts on eugenicism, sectarianism and misogyny in Murphy and First Love. The aim is not to exculpate Beckett from all charges of prejudice, only to complicate issues of complicity in a theocratic hetero-patriarchal society.
\end{abstract}

Key Words. Beckett, Biopolitics, Ireland, Censorship, Parody.

Resumen. En su enérgica crítica de estudios anteriores, Lloyd (Meadhbh) Houston percibe la presencia de un "eugenismo sectario" en las obras de Beckett. Es una afirmación sorprendente que presenta algunos problemas. Sugiero que, en particular, Houston ignora la cuestión del tono, concretamente, el uso de la parodia por parte de Beckett. En mi respuesta a la crítica de Houston, presento algunas ideas sobre el eugenismo, el sectarianismo y la misoginia en Murphy y First Love. El objetivo no es exculpar a Beckett de acusaciones de prejuicio, sino profundizar en cuestiones de complicidad en una sociedad teocrática y heteropatriarcal.

Palabras clave. Beckett, biopolítica, Irlanda, censura, parodia.

As critics have noted, the unpublished essay "Censorship in the Saorstat" is an important source for discussion of Beckett's views on Irish biopolitics (Purcell; Houston). In a forceful critique of previous work, Lloyd (Meadhbh) Houston seeks to complicate our understanding of Beckett's relationship to eugenical discourse. To date, critics have missed the point, they suggest, offering an "exculpatory" reading that obscures Beckett's anti-Catholic prejudice (548). Previous criticisms fail because "staked upon a straightforward opposition between Beckett and the repressive Catholic sexual culture that the Censorship Act is taken to embody" (548). A "presentist desire" to place Beckett on the right side of history after the Holocaust obscures the true stakes of his position $(548 ; 557)$. In their drive towards 
exculpation, previous critics have misrepresented Beckett as an "uncomplicated champion" of reproductive rights (554), offered a "rosy image of his advocacy of abortion" (562), while projecting a "feminist outlook" onto him (555):

In contrast to the ethically valorous and politically subversive rejection of the nativist fertility drive with which [previous critics] identify the story, a sensitivity to ... cultural resonances reveals that the enflamed elephant in the room in Premier amour/First Love is its deployment of a eugenically inflected and sectarian narratorial perspective ... . This is not to suggest that Beckett's perspective is identical with that of the narrator. It is, nevertheless, to acknowledge the presence of flashes of a eugenically inflected sectarian animus against, or, at the very least, anxiety about unchecked Irish Catholic fertility and its cultural and political ramifications in Beckett's work which finds its roots in his experiences of and response to the Censorship of Publications Act. In the context of an author whose oeuvre is often read as an exemplary response to the horrors of the Holocaust and the eugenic logic through which it was justified, such resonances cannot simply be ignored or wished away. (563)

It is a daring intervention, but there are problems with how Houston makes their case. In the passage just cited, for example, there is a significant qualification of what is being asserted. The "flashes of a eugenically inflected sectarian animus" that have been ignored become, of a sudden, "anxiety about unchecked Irish fertility", which is very different. The latter has been observed before, ironically by one of the critics Houston excoriates (Kennedy, All that Fall). The former claim is new. It is a significant charge, published in one of Oxford's leading journals. And Houston goes further: previous work was not scholarly at all but "hagiographic" (557). Setting hagiography aside, they claim to "offer a fresh and more nuanced account of the political stakes of [Beckett's] obscene antenatal [sic] aesthetic" (557).

The resulting corrective is audacious, but not without its problems. It is fresh, certainly, but not, for all that, more nuanced. For one thing, in seeking to make good their claims, Houston is careless with evidence. We are told that Beckett's censorship essay "is most commonly written off as a piece of hack-work" (550), and referred to a single letter from Beckett to MacGreevy. We are told that Murphy has "long been considered" Beckett's most "explicit response" to censorship, then referred to a single critic (557). And this problem of overstatement extends to Houston's own arguments (as the charge of hagiography suggests). They tend to convert negative claims (Beckett was against state control of fertility) into positive positions (Beckett was a feminist), before moving to demolish them.

When the appeal to past scholarship is not cavalier, it is confusing. At one point, Houston cites my own work as proof of the narrator's inability to leave it all behind at the conclusion of First Love, wishing to "extend" that insight to the composition of the story as whole (558-9). A page later, I have simply failed to address the ambivalence with which abortion and departure are depicted (560). This is confused (and confusing) scholarship, and the integrity of the argument suffers as a result. Houston's most significant charge, in their own estimation, is that presenting Beckett's position as "intrinsically valiant" risks "conforming to the logic of Foucault's 'repressive hypothesis"" (548). It is an intriguing claim, but one that is neither substantiated nor developed. Instead, criticism is given over to self-evidence. Houston writes as though a charge of sectarian eugenicism can be assumed and previous scholars twitted for refusing to accept it.

This is a lot to be concerned with already, but it matters less than the problem of Houston's own conclusions. Their avowed purpose is to first demonstrate Beckett's "sectarian eugenicism" in "Censorship in the Saorstat" and Murphy, before showing how it is subjected 
to "pressure" after the War, in Premier Amour/First Love (546). Vichy, we are told, changes things: an argument first made by Andrew Gibson. It is only when Beckett discerns the links between Vichy, Ireland and his own ethnic prejudice, that he moves to re-evaluate his position. This sounds plausible. Yet, as the guiding line of argument it quickly disappears and, by the time Houston is finished, First Love feels more egregious than its precursors:

the only 'brón' Beckett's narrator appears to feel is that he may have conceived a child with a physically defective prostitute, whose unintelligible singing of 'old folk songs', association with a fragment of unattributed Irish, and unwillingness to abort the child, suggest a Gaelic cultural affiliation and a Catholic heritage the propagation of which the narrator is keen to prevent for eugenic reasons. (563)

This is hardly the "more nuanced" reading we were promised. Houston stakes their superior insight on sensitivity to "cultural resonances" (563). Yet the assumptions that underlie this passage (only Catholics speak Irish, only Catholics refuse abortions, only Catholics sing old folk songs) belie such sensitivity. Our sole evidence that the prostitute is "physically defective" is a squint that fluctuates as a function of the narrator's desire: "the more naked she was the more cross-eyed" (Beckett, Prose 44). And the implication throughout is that all of this reflects Beckett's own position. He has subjected his eugenicism to pressure, only to have it rebound in starkest terms. "This is not to suggest" Houston says, that "Beckett's perspective is identical with that of the narrator" (563). But, in the event, it is.

This problem is not unique to Houston, of course. I have been guilty of it myself. But how does any of this get us beyond "a straightforward opposition" between Beckett and Catholic sexual culture (548)? Houston is right, I think, to challenge my uncomplicated binaries, but their own work reproduces them exactly. Ultimately, they are too busy trouncing the hagiographers to turn their own reading to account, and this is a shame, given the evident flair of their writing which, given the nature of what they assert, requires to be taken seriously. Overall, in my view, Houston's piece is founded on a dangerous conflation: that of sectarianism and eugenicism. These are not the same, and we must be scrupulous in our distinction of them.

Like most people born and raised in Ireland in his day, Beckett was sectarian. Not always overtly, by way of his pronouncements. But always implicitly, as a factor of his upbringing. As Tom Inglis notes, it could hardly be otherwise. Religion was such a fundamental marker of personal and social identity that internalisation of a religious habitus was "quasi-inevitable" (Eagleton and Bourdieu 59). Ireland was not just a theocratic state but a "theocratic society", where religion "pervaded all aspects of social life" (Inglis 69). For Pierre Bourdieu, habitus is "embodied history, internalized as a second nature and so forgotten as history" (Logic 56). As such, inculcation to habitus is not something one can simply decide against. Belief is not only conscious, but carried in the body. "Political mythology" becomes "realized, em-bodied, turned into a permanent disposition, a durable way of feeling and thinking" (Logic 69-70). To the extent that one's social field is sectarian, one's personal habitus will be structured around sectarianism. The earlier one is inculcated the less one remembers of such inculcation - the more implicitly it structures one's sensibility (67). In embodying our upbringings, we internalise their values, and these colour our perceptions, actions, postures and preferences, even if/as we disagree with them. One becomes sectarian in ways one cannot even claim to be aware of.

Hence Beckett's self-description as a "dirty low-church P[rotestant] even in poetry" (Letters I 134). He was not describing a choice. It is the enduring tragedy of Ireland's experience after colonialism: a dialectic of identity-in-opposition articulated along religious lines (Deane). Of course, the same was true, on the opposing side, for Irish Catholics, like 
Thomas MacGreevy. One did not need to pursue sectarian ends in Ireland, they structured the very field of possibilities in which selfhood was pursued. Even apostasy was no defence against it. There were Catholic atheists and Protestant atheists. And Catholic bodies were no less sectarian and biddable than their Protestant counterparts. Recall the "well-taught knees" of Austin Clarke's "Martha Blake" (Crotty 18). For this reason, evidence of sectarianism in Irish life matters less, it seems to me, than evidence of what one sought to do with it. Eugenicism was one possible response: a ratification of sectarian prejudice by way of an appeal to biological science. And this is the path W.B. Yeats travelled, with increasing public conviction, until his death in 1939 (Valente). But there were other ways of going about things, including expatriation, impatriation, quietism, even paramilitarism.

In Beckett's case, an early stage of hauteur, of "arrogant otherness" as he described it in 1935 (Letters I 258), gave way to a period of more reflective engagement. Sneering assertions of superiority acceded to self-deprecating explorations of impotence. Or rather, both impulses co-existed both before and after the war, but the balance of emphasis - how indignation comes to be redistributed - shifts: "Molloy and the others came to me the day I became aware of my own folly" (D'Aubarède 217). Undoubtedly, World War Two played a decisive role in this change, though psychoanalysis helped too. In the pre-war writings, Belacqua Shuah and Murphy provide complex vehicles for the condensed expression of Beckett's conflicted relationship to Irish society. In the post-war writings, Vichy France and survivor guilt complicate the reckoning (Gibson; McNaughton).

A notable feature of Beckett's work in this context, and one that is rather lacking in Houston's account of it, is humour. Yeats, at least if his writings are any evidence, was rather earnest. Beckett by contrast, was a comic writer from the beginning. And if we are to understand the problem of sectarianism in his work, a sense of his humour is indispensable. It served many purposes. In The Joke and its Relation to the Unconscious (1905), Freud identifies a hostile tendency in humour whereby repressed aggression finds displaced expression in jokes. To the extent that societies become cultivated (101), opportunities for active retaliation are mitigated, and must find indirect expression. Jokes compensate for the moral precepts of civility, which prescribe silence or forbearance, and are displaced theatres of revenge (101). This is especially so where marked power differentials are at play: "They treat us like shit, so we make them the butt of our jokes". Prevented from "putting our hate into action" (99), we make nasty jokes instead. For Freud, "all renunciation" is difficult for the human psyche (98), leading to what Lauren Berlant terms "cruel optimism": we cling to what harms us (especially our expectations). In the circumstances, humour both mitigates and perpetuates the problem: it makes bearable what, perhaps, should not be (i.e. sectarian theocracies). Combining veiled criticism with aggression, jokes are a displaced means of rebellion against authority: safety valves against acquiescence. But they are also attempts to manage the intimacy of daily encounters in divided societies.

In Ireland, where religiously inspired colonialism poisoned the chalice of interdenominational relations, sectarian humour provided a "psychic constellation" for the release of hatred (Freud 146), but also for the achievement of tentative forms of community. For Freud, it is a sign of profound psychic compatibility when people laugh at the same joke (147). To navigate the difficult business of everyday life, the Irish appealed to humour both to assert and test ethnic boundaries (Barth). Banter, as it is called, entails ongoing assessment of possible common ground. That is how Freud explains the "unreliability" of humour: the risk it entails. The right joke told at the wrong time, or to the wrong person, is disastrous (142). But if it hits the mark, it provides the inestimable pleasure of sudden relief from pretence (103), and promotes fellow-feeling. As such, humour proliferates in adversity. It is a coping mechanism. In this light, we can identify one main problem with Houston's reading of Beckett's "Censorship": it ignores the issue of tone. 
A key term in Houston's essay is "resonates with", which occurs (in variation) 10 times. It is a suitably ambiguous phrase, since they cannot decide if "Censorship" is a "parodic appropriation" of eugenical discourse (550), or in covert sympathy with it. In the circumstances, their chosen term - "resonates with" - defers the reckoning. Beckett certainly sounds like a eugenicist at times in his writing, particularly in his more audacious pronouncements: "Sterilization of the mind and apotheosis of the litter suit well together" ("Censorship" 87). But resonance is not the same as ratification. We cannot simply take this stuff at face value. If one danger is exculpation from charges of eugenicism, another is tonedeaf readings that ignore the issue of parody. The term "degeneration" does not appear in Houston's analysis, and this is important because it is degeneration theory, rather than eugenics, that Beckett is parodying. In Judith Butler's terms, he works both "to reiterate and to oppose" degeneration theory by a process of "subversive repetition" (Butler 124; 133). In "Censorship", I am suggesting, Beckett writes as a kind of degeneration-theorist-in-drag, replicating the discourse in order to scrutinise its founding assumptions.

This helps to explain the issue of resonance. By its very nature, parody is a parasitical method. It is always parody of. And it is to the precise extent that it resonates successfully with an "original" that it becomes viable as parody. Which is why theories of parody, as well as humour, refer so often to the concept of risk: to risky subversion (Butler 134), or risky deconstruction (Chisholm 270). Parodic evocation not only betrays arousal by what is being parodied, it carries the risk of lapsing into mere (or worse, failed) resemblance (the fate of the unwitting doppelganger, or the bad mime). And this, in a sense, is Houston's point: we must "reflect on the ways in which Beckett, in his desire to affront the censorious Free State ..., risks replicating the logic and rhetoric of the Act and its sponsors" (558). Fair enough, but the conflation of "logic and rhetoric" here misses the point. "Censorship" deliberately replicates the rhetoric of the Censorship Act, but only to undermine its logic. Writing for an English audience, Beckett dons the mantle of Swift. It is a kind of "parody-mime", like Luce Irigaray's mimicry of Freudian discourse in The Sex Which is Not One: "a re-representation ... through parody, hyperbole, repetition, metonymy" (Chisholm 274).

Evidence for this occurs throughout the piece. Early on, Beckett describes the Censorship Bill emitting its definitions "as the cuttle squirts ooze from its cod" (84). Houston gives a brilliant reading of the Bill here, as "an ejaculatory discharge from a metonymically evoked codpiece" (552). The image is lifted directly from Max Nordau's Degeneration (1895):

The mystic obliterates the firm outlines of phenomena; he spreads a veil over them, and conceals them in blue vapour. He troubles what is clear, and makes the transparent opaque, as does the cuttle-fish the waters of the ocean. (Nordau 59)

For Nordau, mysticism is an organic brain disorder caused by defective attention and fugitive ideation. In the circumstances, ignorance casts a veil over reality, like squid's ink. By analogy, Ireland's defective legislation obscures the issue of autonomy for citizens of a republic: "a government of the people by the people" ("Censorship" 87). For Beckett, repressive measures can only obscure the integrity of democratic politics. He decries the bill as "morbid sociology" (87), evoking the very essence of degeneration: "morbid deviation from an original type" (Nordau 16). For Nordau, the degenerate is like a bad parody of the good citizen. He evokes the original, but only in his wretched inability to embody them. By analogy, censorship legislation is like a bad parody of good government: it seeks to protect democracy, but only by way of undemocratic, hence self-defeating, policies, i.e. compulsory fertility.

This is not about hagiography, either. Throughout, Beckett mimics degeneration 
theory - as aesthetic of disqualification (Siebers) - in order to discredit it, but that does not preclude him from taking some sectarian pleasure in the process. Rather, his account of Irish statesmen as inkfish achieves multiple goals simultaneously: it parodies degeneration theory, it critiques Irish policy, and it expresses pent-up frustration - hostility - towards Ireland's new governing class. Beckett starts with the elaborate simile of the cuttle-fish and then literalises it. The Irish must "throttle reason itself" if it takes "a form obnoxious to the cephalopods of state" (87). Denigration provides compensatory pleasure in wake of the significant political reversals among Ireland's Protestant minorities, even as it is also turned against those communities themselves. There is a self-deprecating aspect to Beckett's Protestant humour that admits complicity in the problem: "if they are so obviously pathetic, how are they in charge of us?" Yeats struggled with the same issue, but managed it very differently.

Beckett's pleasure is sectarian, certainly, but not, for that reason, eugenic, and this is true both before and after World War Two. For the charge of eugenicism to hold, Beckett would have to advocate selective breeding of superior stock (positive eugenics), or measures against the proliferation of inferior degenerates (negative eugenics). In fact, he sees little to redeem either strategy. Birth was the death of us all. This does not mean that Beckett could not tell the difference between one death and another. It just means he was not given to promotion of "the best" or disqualification of "the worst" in his writing. If anything, he cultivates degenerate perspectives. Assessing the issue requires that we balance the evidence carefully. If we cite the Lynch family in Watt as evidence of sectarian eugenicism, we have to situate them against the utter impotence of Mr Knott in the same work: where Catholics are too wretched to endure, Protestants are too impotent to matter. In the manuscripts, the degeneracy of all concerned is asserted relentlessly (Kennedy, "Big House"). And this is not about Vichy. In work before the war, the 1933 story "Echo's Bones" for example, Beckett confronts Protestant hopes of reinvigoration with a satirical contempt that leaves the Irish Rosary in its wake. Twenty years on, in All that Fall (1956), impotence is ever more the ubiquitous condition of Ireland's Protestant enclaves. In the circumstances, evidence of compensatory violence against symbols of Irish state power recur throughout Beckett's oeuvre, embodied, most memorably, in the fate of the civic guard. There was no "animal" Beckett loathed more profoundly, he told Thomas MacGreevy in 1937, and, for years, they served as objects of displaced rancour at the "loutish complacency" of the Irish Free State generally (Letters I 555). The clubbing scene in Mercier and Camier is only the most shocking example. Comic writing, no less than humour, puts proscribed hate into action.

No one reading Beckett can doubt the extent to which he hated Irish theocracy, but few will assent to the claim that he espoused eugenicism in response. W.B. Yeats was the eugenicist, and Beckett challenged him relentlessly. If this sounds like an uncomplicated binary, in a sense, it is. Certain issues invite clear boundaries, and sectarian eugenicism is one of them. When Beckett travelled to Germany in 1936, it was not to receive a literary award from the Nazis, but to study degenerate art (McCormack; Nixon; Heffer). His sympathy, if sympathy there was, was with "the degenerates". An example relevant to the present context is Beckett's representation of prostitutes, a misogynist mainstay of degeneration discourse. As Houston points out, I fail to address Beckett's misogyny in previous readings (560), and I can address it only briefly here. It remains a neglected area in Beckett studies, even as important work has been done (Ben-Zvi, Bryden, Kim, McMullan, Stewart).

In one sense, it resembles the problem of sectarianism in theocratic societies. Under patriarchy, misogyny is a precondition of masculinity. As the prime structuring feature of the patriarchal order, it is inescapable. Only a dismantling of patriarchy, and the abandonment of its categories of identification, could change that. To the extent that one is masculine, identifies as such, or is accorded the privileges attendant on it, one enters structural complicity 
with misogyny, whatever else one might do about it. For Pierre Bourdieu, in fact, given the problem of internalized sexism, there is no outside to the problem for either sex in a patriarchal society:

Being included, as man or woman, in the object that we are trying to comprehend, we have embodied the historical structures of the masculine order in the form of unconscious schemes of perception and appreciation. When we try to understand masculine domination we are therefore likely to resort to modes of thought that are the product of domination. (Masculine 5)

Here, as with sectarianism, one is misogynist in ways one cannot even account for. Attempts to analyse it are likely themselves misogynist. Claims to be "beyond it" seem tenuous in the extreme. And here again, perhaps, evidence of misogyny matters less than what one tries to do with it.

This, for me, is where the distinction between early and mature Beckett, the pre- and post-war work, becomes important. Premier Amour/First Love does, it seems to me, subject Beckett's earlier misogyny to pressure, but does so in a way that registers continuing implication in the problem. There is no question of ascribing a "feminist outlook" to the piece. Under patriarchy, the problem of misogyny is intractable. One would not expect Beckett to have escaped it. Houston confronts the issue in stark terms, and identifies uncomfortable moments. The passage about Miss Counihan concludes on an unpromising note:

For an Irish girl, Miss Counihan was quite exceptionally anthropoid. Wylie was not sure he cared altogether for her mouth, which was a large one. The kissing surface was greater than the rosebud's, but less highly toned. Otherwise she did. It is superfluous to describe her, she was just like any other beautiful Irish girl, except, as noted, more markedly anthropoid. (in Houston 557)

Taking the term anthropoid to refer to Miss Counihan's "ape-like" features, Houston characterises this as "anachronistic racist slander" (557). Counihan as "evolutionary hangover" (557). Yet, the term "anthropoid" means "resembling humans", which changes things somewhat. It doesn't make the problem go away, we just need to be more careful. The claim of Counihan's exceptionality does suggest that Irish girls, generally, do not resemble humans, and here, again, issues of tone and method are important. Here, the issue of parody does not arise, and there is no question of subversive resonance. Beckett, using free indirect style, "the Uncle Charles principle" he learned from Joyce (Kenner), has Wylie think in objectifying discourse that evokes the simianizing cartoons of the nineteenth century (Houston 558). Fiction writers have to ventriloquize positions other than their own. It would be difficult to write otherwise. But crucially here, the voice of the narrator chimes in to restate the diagnosis: "There is no point in describing her ...". This implicates Beckett more obviously in the slur. His character has a go, and he relishes the occasion. The humour is of the hostile kind analysed by Freud, directed at woman as metonymic objects of male disdain, and bound to offend many. It was this aspect of misogyny that Beckett came to regret and to understand better in himself after the war.

Here again, parody is central to how that insight is expressed. As scholars have pointed out many times, patriarchs both desire and resent their need for women: it is a combination of "fear, awe and disgust" (Spelman 121). And if hostile humour responds to obstacles placed in the way of desire (Freud 98), the prevalence of misogynistic humour in patriarchal society is no mystery. It, too, is a displaced theatre of revenge, substituting for 
proscribed aggression, as well as a vehicle for banter, flirtation, social intercourse. In The Joke, Freud is particularly partial to jokes about marriage: men can't have what they want, or else they can't want what they have. He has occasional qualms about the unflattering portraits he peddles, but it does not prevent the litany (Carey xxiii). He's getting off on it, even in the business of analysing it. Like Beckett's more obviously misogynist moments, this aspect of Freud's joke book tends to feel less and less funny with time. Under patriarchy, "the social order functions as an immense symbolic machine tending to ratify the masculine domination on which it is founded" (Bourdieu, Masculine 9). And both Freud's joke book and Beckett's prose are both product and process of that machine. Again, there is no question of an exculpatory reading of either figure, since, as long as patriarchy is in effect, exculpation is not possible.

Nevertheless, if being misogynist is not simply a decision one can unmake, it is, all the same, a tendency one can learn to abjure. There are misogynists who try, and there are misogynists who don't. There are those who struggle with their internalized prejudices, and those who presume upon them. Things changed for Beckett, fitfully, as a reading of his portrayal of both Celia and Anna/Lulu demonstrates. Both are prostitutes yet, in both cases, Beckett offers sympathetic portraits of dignified women faced with more or less objectionable men (Murphy is perhaps the more likeable). Murphy is an important precedent to First Love in that it provides an account of a hard-working woman funding the spurious fantasies of a man who wishes only to "come alive in his mind" (6). Notoriously, Murphy refuses to work and, in the absence of his contribution, Celia chooses to earn money on the street. Murphy is not unhappy with this arrangement. It is an almost identical case in "First Love," which is a later working through of the problems raised (and foreclosed upon) in Murphy: "Are we to infer from this that I loved her with the intellectual love that drew from me such drivel in another place?" (Prose, 35). That other place, is Murphy. Again, we have a Cartesian fantasist, and again the narrator $(\mathrm{N})$ is living in denial. In N's current version of events, he must be with Lulu in order to be free of her: "I did not feel easy when I was with her, but at least free to think of something else than her" (39). In a classic statement of the Classical root of misogyny, she is a snare: an impediment to freedom in the mind (Spelman). $\mathrm{N}$ is a Platonist, for whom woman is the shit that gets in the way of mindfulness. But we are not meant to take his word on things. For one thing, his freedom, so-called, implicates him at another level of indebtedness - the economic - which, in a rare moment of direct speech, Lulu/Anna makes clear:

I was more seriously disturbed by other sounds, stifled giggles and groans, which filled the dwelling at certain hours of the night, and even of the day. I had given up thinking of her, quite given up, but still I needed silence to live my life. ... So a fat lot of help it was when, having put the question to her, I was told that they were clients she received in rotation ... . So you live by prostitution, I said. We live by prostitution, she said. (Prose 43)

Here, financial dependency (itself disavowed) figures all the other (similarly obscured) dependencies on women (and their bodies) that structure patriarchal society. The effect is not to demean women, but to betray the spurious basis of masculine autonomy: of N's fantasies of freedom. It is different from those examples where narrator and character combine in gleeful denigration of the woman in question. Far from indicting Lulu, the passage betrays $\mathrm{N}$, as a scrounger as well as a solipsistic ass. "In this figure", as Freud says of Heine's Baron Gumpelino, "the poet is parodying himself" (138). He is subjecting his earlier treatments of women to pressure, as Houston suggests. For Freud, hostile jokes work particularly well "against oneself, or ... against a person in whom that self has a share" (108). Parodying an 
earlier version of himself, a self in whom he still has a share, Premier Amour/First Love revisits Beckett's past sins. But it remains mired in the problems it represents, as Bourdieu says it must.

Turning elsewhere in the story, it helps to put self-parody into play. In the long description of the striptease that forms the basis for Houston's charge of sectarian eugenicism, the same dynamic is evident: "She gazed at me with her big eyes whose colour I forget, with one big eye rather, for the other seemed riveted on the remains of the hyacinth. The more naked she was the more cross-eyed" (Prose 44). Certainly, this is misogynist, but $\mathrm{N}$ is not a mere mouthpiece for Beckett (nor a particularly observant witness). Houston reads the passage straight: the squint betrays Beckett's "eugenicist perspective", "implicitly identifying Anna as one of the 'human weeds' ... eugenicists had been so anxious to eliminate" (560). If we factor in parody here, the fact that her squint fluctuates as a function of N's desire betrays the projective nature of his account of her. It is not just that his characterisation of her changes: his very perception of her fluctuates as a function of his arousal. Under patriarchy, as Bourdieu suggests, schemes of thought record as differences of nature "variations and distinctive features (of physique, for example) which they help to make exist at the same time as they 'naturalize' them" (Masculine 8).

Here again, Beckett's narratological method works to implicate $\mathrm{N}$, not humiliate Anna. Having discredited N's spurious claims to financial autonomy, Beckett betrays the somatically entrenched nature of his (own) misogyny. Beckett is parodying the dynamic whereby masculine dread (and/as desire) is projected onto woman as physical and moral deformity. It is less about eugenics, and more about internalised misogyny as structural distortion. As self-parody, this is Beckett's attempt to hold earlier versions of himself accountable without, for all that, managing to exculpate himself, or transcend misogyny altogether. It is a kind of self-deprecating admission from within the immense symbolic machine of masculine domination. First Love involves a kind of double-agency that works both to reiterate and to oppose misogynist sentiment. It is both misogynist and anti-misogynist at once as, perhaps, we all are. As such, it both challenges masculine domination and perpetuates it, underlining the intractability of the problem Beckett was struggling to account for. In patriarchy, misogyny coincides with masculinity: the articulation of the one presumes the denigration of the other. Self-parody admits the problem, without presuming to get beyond it.

\section{Works Cited}

Barth, Fredrik. Ethnic Groups and Boundaries. London: Waveland Press, 1998.

Beckett, Samuel. Murphy. London: Calder, 1993 (1938).

- Disjecta: Miscellaneous Writings and a Dramatic Fragment. London: Calder, 1983.

The Complete Short Prose, 1929-1989. New York: Grove Press, 1995.

. The Letters of Samuel Beckett: Volume 1; 1929-1940. Eds. Martha Dow Fehsenfeld and Lois More Overbeck. Cambridge: Cambridge University Press, 2009.

Berlant, Lauren. Cruel Optimism. Durham: Duke University Press, 2011.

Ben-Zvi, Linda, ed. Women in Beckett: Performance and Critical Perspectives. Urbana and Chicago: University of Illinois Press, 1990.

Bourdieu, Pierre. The Logic of Practice, Stanford: Stanford University Press, 1990. Masculine Domination. Stanford: Stanford University Press, 2001.

Bryden, Mary. Women in Samuel Beckett's Prose and Drama: Her Own Other. Lanham: Barnes and Noble, 1993. 
Butler, Judith. "Imitation and Gender Insubordination". The Judith Butler Reader. London: Blackwell, 2004 (1990). 119-137.

Carey, John. "Introduction". The Joke and its Relation to the Unconscious. Harmondsworth, Penguin, 2002. vii-xxviii.

Chisholm, Dianne. "Irigaray's Hysteria”. Engaging with Irigaray. Eds. Carolyn Burke, Naomi Schor and Margaret Whitford. New York: Columbia University Press, 1994. 263-283.

Crotty, Patrick, ed. Modern Irish Poetry: an Anthology. London: Blackstaff, 1995.

D'Aubarède, Gabriel. "Interview". Samuel Beckett: the Critical Heritage. Eds. Lawrence Graver and Raymond Federman. London: Routledge and Kegan Paul, 1979 (1961). 215-217.

Deane, Seamus. "Imperialism/Nationalism". Critical Terms for Literary Study. Ed. Frank Lentricchia. Chicago: Chicago University Press, 1995. 354-368.

Eagleton, Terry and Pierre Bourdieu. "Doxa and the Common Life". New Left Review 1. 191 (1992): 267-273.

Freud, Sigmund. The Joke and its Relation to the Unconscious. Harmondsworth: Penguin, 2002 (1905).

Gibson, Andrew. "Beckett, Vichy, Maurras, and the Body: Premier amour and Nouvelles". Irish University Review 45. 2 (2015): 281-301.

Heffer, Byron. "Unformed Life in Beckett's The Unnamable". Beckett Beyond the Normal. Ed. Seán Kennedy. Edinburgh: Edinburgh University Press (forthcoming).

Houston, Lloyd (Maedhbh). "Sterilization of the Mind and Apotheosis of the Litter': Beckett, Censorship and Fertility”. The Review of English Studies 69. 290 (2018): 546-564.

Inglis, Tom. "Religion, Identity, State and Society". The Cambridge Companion to Modern Irish Culture. Eds. Joe Cleary and Clare Connolly. Cambridge: Cambridge University Press, 2005. 59-75.

Kennedy, Seán, “'A Lingering Dissolution': All that Fall and Protestant Fears of Engulfment in the Irish Free State". Assaph: Studies in the Theatre 17/18. Ed. Linda Ben Zvi. (2003): 247-262.

. "Bid us Sigh on from Day to Day': Beckett and the Irish Big House". The Edinburgh Companion to Beckett and the Arts. Ed. S.E. Gontarski. Edinburgh: Edinburgh University Press, 2014. 222-236.

Kenner, Hugh. Joyce's Voices. Dublin: Dalkey Archive Press, 2007.

Kim, Rina. Women and Ireland as Beckett's Lost Others: Beyond Mourning and Melancholia. London: Palgrave, 2010.

McCormack, W.J. Blood Kindred: W.B. Yeats: the Life, the Death, the Politics. London: Pimlico, 2005.

McMullan, Anna. Theatre on Trial: Samuel Beckett's Later Drama. London: Routledge, 1993.

McNaughton, James. Samuel Beckett and the Politics of Aftermath. Oxford: Oxford University Press, 2018.

Nixon, Mark. Samuel Beckett's German Diaries, 1936-37. London: Continuum, 2011.

Nordau, Max. Degeneration. New York: Appleton, 1895.

Purcell, Siobhán. "Beckett and Disability Biopolitics: The Case of Cuchulain". Estudios Irlandeses 14.2. Special Issue: Samuel Beckett and Biopolitics. Ed. Seán Kennedy (2019): 52-64.

Siebers, Tobin. Disability Aesthetics. Ann Arbor: University of Michigan Press, 2010.

Spelman, Elizabeth. "Woman as Body: Ancient and Contemporary Views". Feminist Studies 8.1 (1982): 109-131.

Stewart, Paul. Sex and Aesthetics in Samuel Beckett's Work. London: Palgrave, 2011. 
Valente, Joseph. "Aging Yeats: from Fascism to Disability". Irish Literatures in Transition. Ed. Marjorie Howes and Claire Connolly. Cambridge: Cambridge University Press (forthcoming).

Seán Kennedy is Professor of English at Saint Mary's University, Halifax. He is currently editing two volumes, Irish Shame, with Joseph Valente and Sara Martín-Ruiz, and Beckett Beyond The Normal (Edinburgh University Press).

sean.kennedy@smu.ca 